\title{
El sur del Sur: cronotopías identitarias de la Patagonia en el cine argentino contemporáneo.
}

\section{The South of the South: Patagonian Identity Chronotopies in Argentinian Contemporary Films.}

\begin{abstract}
Resumen
Este artículo propone un trabajo de interpretación, derivado del análisis textual y contextual, de diez films argentinos en los que se re-presenta al territorio patagónico: La película del rey (C. Sorín, 1986); Gerónima (R. Tosso, 1986); Guerreros y cautivas (E. Cozarinsky, 1989); La nave de los locos (R. Willicher, 1994); Caballos salvajes (M. Piñeyro, 1995); Flores amarillas en la ventana (V. Ruiz, 1996), El viento se llevó lo qué (A. Agresti, 1998); Mundo Grúa (P. Trapero, 1999); Invierno mala vida (G. Cramer, 1999) e Historias mínimas (C. Sorín, 2002). Identificaremos relaciones intertextuales, cuyos sentidos pugnan por imponerse, y conocer así las formas precisas de la dimensión cultural, social e histórica de un conjunto de textos fílmicos. La hipótesis general es que los films expresan indicialmente el tipo de experiencias que la mutación epocal neoliberal va marcando en los cuerpos y las subjetividades de los sujetos. Mayoritariamente se impone una representación de Patagonia for export a partir de dotarla de una naturaleza exótica o una inmensidad enigmática para la contemplación o la aventura transitoria. Este corrimiento expresa a nivel simbólico cambios que el neoliberalismo produjo en toda América Latina, pero que encuentra al sur del sur específicas coordenadas e imaginarios.
\end{abstract}

Palabras claves

Cine argentino, Patagonia, cronotopía.

\begin{abstract}
This paper proposes a work of interpretation, from a textual and contextual analysis, of ten Argentinian films in which the Patagonian territory is re-presented: : La película del rey (C. Sorín, 1986); Gerónima (R. Tosso, 1986); Guerreros y cautivas (E. Cozarinsky, 1989); La nave
\end{abstract}


de los locos (R. Willicher, 1994); Caballos salvajes (M. Piñeyro, 1995); Flores amarillas en la ventana (V. Ruiz, 1996), El viento se llevó lo qué (A. Agresti, 1998); Mundo Grúa (P. Trapero, 1999); Invierno mala vida (G. Cramer, 1999) e Historias mínimas (C. Sorín, 2002). Intertextual relations, whose meanings struggle to impose themselves, will be identified. A more precise idea of the cultural, social and historical dimension of a set of films will thus emerge. The general hypothesis is that the films show signs of the kind of experiences that the epochal neoliberal mutation molds in the subjects' bodies end subjectivities. Mostly a representation of a "for export" Patagonia appears, with an exotic nature or an enigmatic immensity for contemplation or transitory adventure. This misconception shows at a symbolic level changes that the neoliberalism produced in all Latin America, but which in the south of the south finds specific coordinates and stereotypes.

Keywords

Argentinian films, Patagonia, chronotopy.

\section{Introducción}

Los films en su particular intersección/relación entre el mundo representado y la realidad social, dan cuenta de las disputas de las culturas y sus memorias. Concebimos así a los textos fílmicos como históricos, producto(re)s de una época determinada; para lo cual es necesario preguntarse por lo visible y lo no visible, las presencias y ausencias, y su relación con el momento de producción de los films. En este sentido, siguiendo a Clara Kriger, es posible entender al cine “como un espacio de mediaciones en donde los procesos económicos, sociales y políticos dejan de ser exteriores a los procesos simbólicos y donde estos últimos constituyen el sentido social y no sólo lo expresan" (Kriger, 208).

En esa línea coincidimos asimismo con Ana Amado quien sostiene más extensamente que el cine es un

[...] discurso social privilegiado por su capacidad de atravesar los circuitos representacionales de una época o de una cultura, construye representaciones según procedimientos específicos, en tanto el registro visual trabaja y metaboliza sentidos provenientes de diferentes niveles de la realidad -entendida ésta como mundo físico y a la vez entramado de relaciones sociales-. Esta 'metabolización' implica, por lo tanto, que las 
imágenes promueven perspectivas que trascienden el mero registro o duplicación de lo dado. (Amado 43)

Por otra parte, las ideas y las manifestaciones textuales que se tienen sobre los lugares son mediaciones efectivas de los espacios; éstas siempre representan un recorte y evidencian una perspectiva que no se reduce a necesidades expresivas individuales (Mellado 2015). Por ello, el análisis de los textos fílmicos permite dar cuenta no sólo de los regímenes de visibilidades sino también de invisibilidades y de los diferentes modos de concebir/sentir/disputar los sentidos de la historia y de los espacios-territorios, sentidos que forman parte de su construcción.

El presente artículo propone un trabajo de interpretación, derivado del análisis textual y contextual, de diez films ficcionales argentinos realizados entre 1986 y $2002^{1}$ en los que se re-presenta al territorio patagónico: La película del rey

${ }^{1}$ El período de referencia, 1986-2002, ha sido delimitado a partir de las características que asumió la hegemonía del capital financiero en la región patagónica. En dicha región el modelo de planificación estatal afín a la etapa anterior (modelo de "polos de desarrollo"), y característico del capitalismo industrial, fue reemplazado por otro tipo de planificación acorde al interés del capital financiero. Este traspaso se dio a mediados de los años ' 80 cuando los sectores neoliberales impusieron su política y se interrumpió la promoción estatal de nuevos emprendimientos. Las consecuencias de esto fueron verdaderamente visibles recién en la década siguiente. Por otro lado, la búsqueda y consecución de textos fílmicos cuyo mundo representado está situado en la Patagonia también nos permite, desde una perspectiva ubicada en una historia social de la cinematografía argentina, proponer una puntuación posible en el año 1986. Durante ese año se estrenaron dos películas que consideramos claves en la historia del cine argentino por la impronta estética y temática que marcaron cada una de ellas, aunque por diferentes razones. Nos referimos a Gerónima (Tosso, 1986) y La película del rey (Sorín, 1986). La primera, es uno de los films que en el período posdictarorial retoman el denominado cine testimonial y es de referencia obligada para quienes quieran reflexionar sobre este tipo de cine. La película del rey puede considerarse como antecesora del denominado "nuevo- nuevo cine argentino".

El final del período de nuestra investigación coincide con el cambio de siglo, que para Argentina significó, concretamente en el año 2002, la salida de un modelo económico basado en la convertibilidad (paridad cambiaria establecida por el Estado). La modificación de esta variable de la economía nacional, y la consecuente devaluación, afectó -entre muchas otras cosas- los costos y los modos de producción cinematográfica. Los múltiples conflictos y las diferentes formas que éstos adquirieron llegaron al paroxismo con el estallido social conocido como Argentinazo, que se constituyó en un hito histórico con implicancias profundas no sólo a nivel económico, sino también social, cultural y simbólico, expresadas e interpretadas de diferentes maneras por los discursos artísticos, entre ellos los cinematográficos. El período abarcado posibilita observar hasta dónde calaron las políticas neoliberales y las resistencias -con su variedad de formas- que éstas encontraron, así como las especificidades, particularidades y 
(Carlos Sorín, 1986), Gerónima (Raúl Tosso, 1986), Guerreros y cautivas (Edgardo Cozarinsky, 1989), La nave de los locos (Ricardo Willicher, 1994), Caballos salvajes (Marcelo Piñeyro, 1995), Flores amarillas en la ventana (Víctor J. Ruiz, 1996); El viento se llevó lo qué (Alejandro Agresti, 1998), Mundo Grúa (Pablo Trapero, 1999), Invierno mala vida (Gregorio Cramer, 1999) e Historias mínimas (Carlos Sorín, 2002). Esto posibilitará identificar relaciones intertextuales, cuyos sentidos pugnan por imponerse, y conocer así las formas precisas de la dimensión cultural, social e histórica de un conjunto de textos fílmicos.

La hipótesis general es que los films expresan indicialmente el tipo de experiencias que la hegemonía del capital financiero -o lo que Gilly, Gutiérrez y Roux denominan mutación epocal neoliberal (2006)- ${ }^{2}$ va marcando en los cuerpos y las subjetividades de los personajes-sujetos. Mayoritariamente se impone una representación de Patagonia for export ${ }^{3}$ a partir de dotarla de una naturaleza

contingencias que tal proceso adquirió en la región interpretada por los textos fílmicos y estudiada/reinterpretada por nosotros.

${ }^{2}$ Citamos en extenso la siguiente definición porque, por un lado, abarca las distintas formas en que se expresa el neoliberalismo y, por otro, porque permite visualizar que este proceso histórico tal y como se produce en Patagonia es coincidente, en sus rasgos generales, con la forma que adquirió en América Latina: "1) Por un lado, el neoliberalismo es una ofensiva política y económica en toda la línea contra la población trabajadora urbana y rural... El neoliberalismo ha establecido una nueva forma de uso de la fuerza de trabajo basada en su más radical depreciación, en su empleo y extensión bajo modalidades anómalas e informales, en formas intensas y densas de explotación [...] [S]e despliega en una sistemática y permanente pelea por imponer condiciones intolerables para el uso de la fuerza de trabajo y es, en este sentido, una continua acción de sometimiento de la capacidad de trabajo. [...] 2) El neoliberalismo consiste también en una gigantesca acción de despojo, de acaparamiento, apropiación y monopolización de la riqueza social creada y acumulada por muchas generaciones. La ola de privatizaciones de empresas estratégicas de petróleo, energía eléctrica y agua anteriormente de propiedad pública, de la seguridad social y los fondos de pensiones, de la tierra y los servicios en todos los países de América Latina, con sus variantes locales de capitalización, apertura de mercados o directamente entrega al capital transnacional, es la forma en que el saqueo se ha llevado y se sigue llevando a cabo. [...] 3) El neoliberalismo ha ido de la mano con el desmantelamiento de las estructuras sociales que permitían la posibilidad de ejercicio de determinados derechos colectivos anteriormente reglamentados y habilitaban ciertas formas de participación política. [...] 4) El neoliberalismo, sus ideologías y sus instrumentos y medios de comunicación masiva encarnan además una voluntad dominante de adelgazamiento sistemático $\mathrm{y}$, si es posible, de desvanecimiento de los vínculos y los niveles de solidaridad y de fraternidad entre los humanos en general y entre los oprimidos en especial." (Gilly, Gutiérrez y Roux 107-109).

3 Si bien el rótulo Patagonia for export es usado coloquialmente, aquí se retoma de la caracterización que realiza Alejandro Gasel para la literatura en su trabajo "De cuerpos y 
exótica o una inmensidad enigmática para la contemplación o la aventura transitoria de viajeros-consumidores contemporáneos. Este corrimiento expresa y difunde a nivel simbólico uno de los cambios que el neoliberalismo produjo en el territorio en el plano económico-material. Frente a la crisis de otras actividades económicas, uno de los rubros que más se desarrolló en Patagonia en el período analizado fue el turismo -especialmente el internacional dirigido a personas de altos ingresos- ${ }^{4}$ y entendemos que los films producidos en este período forman parte de los discursos que exhiben sintomáticamente el cambio de estructura económica productiva a otra de servicios. ${ }^{5}$

territorios. Itinerarios de la Patagonia Austral en la narrativa argentina reciente (1982-2008)". Gasel no la plantea como una representación hegemónica, pero sí la rastrea desde la literatura de Bruce Chatwin donde la Patagonia es reconstruida en el marco de un diario de viaje. "La difusión de la escritura de Bruce Chatwin y la propuesta de lectura crítica (Jenny Haase) han probado que el territorio se presenta como objeto de mercado para ser vendido a un público (norteamericano y europeo) que compraría este producto for export" (Gasel 146). Asimismo, su investigación observa, en consonancia con lo planteado en estas páginas, que las narrativas de poéticas diversas producidas entre 1982-2008 tienen pocas correlaciones entre sí, pero activan imaginarios fuertemente asociados al territorio como lo son: Patagonia como devastación de la subjetividad y Patagonia for export (Gasel 22).

${ }^{4}$ Antes del período reseñado encontramos a San Carlos de Bariloche como el caso más antiguo de actividad turística. Sin embargo, a este destino hay que agregarle las distintas actividades turísticas a lo largo de la cordillera, las visitas al glaciar Perito Moreno, el avistaje de ballenas francas en la Península Valdés, Ushuaia promocionada como la "capital del fin del mundo", las estancias convertidas en hospedajes de lujo, la multiplicación de poblaciones balnearias, el reciente desarrollo del eco-turismo, el turismo de "aventura" y el paleoturismo. Estos son sólo algunos de los lugares y actividades que hacen de la Patagonia un lugar promocionado como "marca registrada" y "paraíso de aventureros" según el discurso producido por las agencias/empresas turísticas. Véase, por ejemplo: Pérez Álvarez (2013), Bandieri (2005), Vejsbjerg (2007).

${ }^{5}$ En un artículo anterior en el que se analizaron las representaciones de las actividades económicas en películas filmadas en la región durante el período 1986-2006, advertíamos que: "La actividad económica predominantemente representada en este conjunto de films es la actividad terciaria ligada a comercios relacionados con las personas que están de paso (estaciones de servicio, hoteles y demás tipos de alojamientos, bares, restaurantes, cafeterías apostados sobre las rutas asfaltadas o caminos de tierra) en detrimento de las imágenes de actividades de las personas que viven y trabajan en los diferentes lugares. Esto nos permite concluir que la Patagonia es vista como un lugar de paso, idea que se refuerza además mediante la forma en que se muestra y representa a los personajes, esto es que sobresalen y están por sobre el paisaje. [...] La segunda actividad que aparece en orden de importancia (en términos visuales) es la actividad de servicios turísticos (La nave de los locos, Todas las azafatas van al cielo y El aura), que a su vez también refuerza la idea de la Patagonia como un lugar de paso, como un lugar donde predomina el paisaje, "lo natural". Esto hace pensar -en términos de Sorlin- en lo "visible" en una época determinada, porque no es casual que las actividades que cobran mayor relevancia en las películas sean al mismo tiempo actividades que mantienen o aumentan su importancia económica en la región durante el neoliberalismo (no es casual que en films donde las 
Este trabajo parte de la premisa de que la región dejó de ser un “ámbito acotado previamente definido por el historiador, para convertirse en una hipótesis a demostrar" (Bandieri, La Patagonia: mitos 391). Por ello, la historia regional entendido lo regional como alternativa analítica para pensar otros espacios y nuevas periodizaciones (Bandieri 2007, 2015)- ${ }^{6}$ no puede prescindir del cine para comprender cómo ha sido pensada-sentida, nominada y mostrada una determinada región, en nuestro caso la Patagonia, ya que sus representaciones forman parte de su construcción, en tanto se asientan en la realidad material en que los sujetos actúan. Es decir, las representaciones se definen por su contenido, pero también pueden definirse como una relación entre sujetos: es la representación que un sujeto se forma de otro. Así, las representaciones no sólo son expresión de las relaciones sociales (y sus complejidades cambiantes) sino que también contribuyen a construirlas (Jodelet, 1984). Aquí seguimos a Lefevre quien entiende a las representaciones, como un sistema de mediación entre el objeto representado y el sujeto que percibe y experimenta. Es importante tener en cuenta que las representaciones no son, en esencia, ni verdaderas ni falsas. Es una operación posterior, una actividad reflexiva la que les otorga verdad y/o falsedad relacionándolas con las condiciones de existencia de quienes las producen (Lefebvre 57). Son verdaderas en tanto ofrecen respuestas a problemas reales, y falsas en tanto disimulan o deforman la realidad que representan. Esto implica que

actividades o proyectos que se representan no forman parte de las consignas neoliberales sean actividades amenazadas o condenadas al fracaso, como por ejemplo en los de Trapero -la construcción de obras de infraestructura o el funcionamiento de un aeropuerto civil y militar- o en La película del rey -la concreción de una filmación-). [E]l turismo creció y se elitizó transformando a muchas ciudades y pueblos, tradicionales y nuevos, en destino de turismo extranjero" (Escobar, Escenas 123-124).

6 Siguiendo a la misma autora la historia regional permite visibilizar los problemas de periodización que perviven en la historia argentina tradicional al no tener en cuenta los procesos diferenciados en cada una de las regiones. Coincidimos con Bandieri en que, a partir de la historia de Patagonia, por ejemplo, la historia regional aporta posibilidades para complejizar y renovar la historiografía argentina sobre todo aquella "demasiado generalizante y encerrada en los límites territoriales del Estado- Nación" (Bandieri, 2015). 
las representaciones contienen un aspecto concreto, las relaciones materiales de existencia; y un aspecto abstracto, lo discursivo y lo ideológico. ${ }^{7}$

Por tanto: la construcción de territorios y espacios regionales es siempre un proceso inacabado, dado que el movimiento constante de la historia implica el cuestionamiento y sustitución de unas representaciones por otras, movimientos que pueden detectarse desde el análisis de la textualidad fílmica.

Adherimos a la noción de hegemonía - definida como proceso histórico concreto, por el cual una clase logra que sus intereses sean reconocidos también como propios por las clases subalternas, incluso si van en contra de sus propios intereses- ${ }^{8}$ para comprender las formas culturales de la dominación en general. Esas formas se materializan en productos culturales simbólicos concretos -en nuestro caso los textos fílmicos- a través de los cuales pueden hacerse inteligibles. Es por eso que postulamos una metodología que desde la mirada histórica justamente indague la historicidad de las propias formas, entendidas éstas como procesos sociales que expresan y configuran al mismo tiempo una historia heterogénea estética y trans-estética, en el sentido de que su estética siempre contiene una politicidad cuya interpretación afecta la concepción que la sociedad tiene de sí misma (Grüner, Foucault 5). Por ello nuestro análisis contiene una fuerte dimensión interpretativa que entiende la inextricable unidad de la historia, la ideología y el estilo, lo que nos lleva a agudizar nuestra mirada sobre la

${ }^{7}$ Respecto a lo discursivo es necesario aclarar que no consiste simplemente en una concatenación de signos y significados. En el discurso intervienen otros elementos que hacen el sentido, como los valores y normas admitidas en una sociedad, los mismos están incorporados a palabras claves, símbolos e imágenes, en suma, representaciones. La representación, incluida desde el principio, abarca la totalidad del discurso y su teoría; las representaciones hacen sentidos que se superponen a significados de palabras, pero no se reducen a ellas (Lefebvre 52).

${ }^{8}$ A la definición gramsciana de hegemonía ya resumida, conviene completarla con la noción de hegemonía culturar propuesta por Raymond Williams, quien plantea que la hegemonía conforma toda una red de prácticas y perspectivas en relación con la totalidad de la vida, que incluyen las percepciones que tenemos de nosotros mismos y del mundo. Es un sistema de significados y valores que se confirman en la práctica. Por lo tanto, "es un sentido de realidad para la mayoría de las gentes de la sociedad, un sentido de lo absoluto debido a la realidad experimentada más allá de la cual la movilización de la mayoría de los miembros de la sociedad -en la mayor parte de las áreas de su vida- se torna sumamente difícil” (Williams, Marxismo 132). Desde esta perspectiva, la práctica y tradición culturales son comprendidas como algo más que expresiones superestructurales de una estructura socioeconómica constituida; se las ubica entre los procesos básicos de su propia formación. 
materialidad y formalidad misma de los textos, para realizar desde su interior un análisis histórico que nos permita evidenciar las "contradicciones, ambigüedades y las profundas huellas de su tiempo" (Kriger 251). Nuestra estrategia interpretativa parte de concebirla como producción de nuevas representaciones e imaginarios que construyen determinados sentidos para los agenciamientos y las identidades sociales -entendidas éstas como procesos en constante configuración, desconfiguración y reconfiguración a través de la espacialidad y la temporalidad a partir de la siempre conflictiva correlación de fuerzas que se despliega de modo incesante en la historia-.

En definitiva, la acción transformadora es la condición misma de la interpretación, porque "la riqueza misma de la noción de praxis está contenida en la idea de que la interpretación puede ser una herramienta crítica, de 'puesta en crisis' de las estructuras materiales y simbólicas de la sociedad en polémica con otras interpretaciones que buscan consolidarse en su inercia" (Grüner, Foucault 2). La cultura entonces puede concebirse como un combate por las interpretaciones. Y ese campo de batalla constituye, en definitiva, el movimiento constante de la historia.

Todo ello nos permite entonces realizar algunas interpretaciones tomando los textos fílmicos analizados, ahora en conjunto, para indicar las zonas de visibilidad y de invisibilidad, las ambigüedades y las contradicciones entendidas como prácticas sociales dominantes, residuales y emergentes en términos de Williams (1980). ${ }^{9}$

${ }^{9}$ En consonancia con nuestro punto de partida teórico en el que abrevamos en las concepciones de Raymond Williams sobre la hegemonía cultural, entendemos que como el resto de las prácticas culturales la cinematográfica puede pensarse en términos de lo que él distinguió como dominante, residual y emergente para pensar la convivencia en el tiempo de diferentes discursos asociados a diferentes proyecciones sobre la organización social. Lo residual expresa ciertas experiencias, significados y valores "que no pueden ser expresados o sustancialmente verificados en términos de la cultura dominante; son, no obstante, vividos y practicados sobre la base de un remanente - cultural tanto como social — de alguna formación o institución social anterior" (Williams, Marxismo 144). Debe recordarse que, a diferencia de lo arcaico, lo residual es aquello que ha sido formado en el pasado pero que aún se halla activo en el proceso cultural no sólo como elemento del pasado, sino como un efectivo elemento del presente. Por emergente, se entienden aquellas nuevas prácticas, nuevos significados y valores, nuevas relaciones y tipos de relaciones que se crean continuamente (Williams, 1980). La cultura emergente depende 


\section{De la Patagonia épica a la Patagonia incierta}

Advertimos algunos corrimientos representacionales respecto de un momento histórico anterior al de esta indagación. Aquellos textos fílmicos producidos entre las décadas de 1930 y 1970, daban cuenta de una Patagonia épica donde los personajes moldeaban a la región -trabajo y sacrificio mediantetransformándola en una espacialidad productiva, plena de posibilidades de progreso. Los personajes de esos films simbolizaban/vehiculizaban el proyecto de la Nación/modernización capitalista en Patagonia haciendo prósperas sobre todo las actividades agrario-ganaderas en el ámbito rural y en menor medida las de las grandes empresas desarrolladas a través del capitalismo de Estado en enclaves. ${ }^{10}$ Los cambios y permanencias en estas representaciones dan cuenta de qué imágenes constituyen lo visible de un medio y de una época. Al decir de Pierre Sorlin:

Las fluctuaciones de lo visible no tienen nada de aleatorio: responden a las necesidades o al rechazo de una formación social. Las condiciones que influyen sobre las metamorfosis de lo visual y el campo mismo de lo visual están estrechamente ligadas: un grupo ve lo que puede ver, y lo

fundamentalmente del descubrimiento de nuevas formas o de adaptaciones de formas. En ambos casos se trata de elementos que, eventualmente, son incorporados o destruidos por la cultura dominante, aun cuando ésta nunca incluye toda la práctica humana y siempre deja resquicios para que surjan elementos residuales o emergentes. En ese sentido, toda práctica cultural puede entenderse en su relación con lo dominante (Silva Escobar y Raurich 65).

${ }^{10}$ En una investigación anterior en la que analizamos algunos films ficcionales del período 19361976 la representación que predominaba era la de Patagonia como naturaleza productiva, como tierra promisoria en la que el desierto, a través de la agencia de los personajes-sujetos, dejaba de ser tal para convertirse en parte de la civilización/Nación/modernidad. Allí lo fundacional reaparecía a través del mito del hacer ya que el trabajo, el sacrificio y la violencia redundaban, en estas narrativas, en elementos necesarios para la incorporación del territorio a la Nación reproduciendo entonces el imaginario de la Patagonia épica. A respecto pueden consultarse: Escobar $(2007 ; 2011)$. Para las representaciones de la región en el cine argentino silente véase: Levinson (2011). 
que es capaz de percibir define el perímetro en cuyo interior está capacitado para plantear sus propios problemas. (Sorlin 60)

En nuestro corpus fílmico actual, las narrativas épicas son la excepción (nos referimos a Guerreros y cautivas) y los personajes ya no son los agentes de la modernización -siempre con connotación positiva- y de la extensión de la Nación en estas tierras. En los textos fílmicos analizados se diversifican los sujetos históricos puestos en pantalla que habitan, llegan o atraviesan la región; las clases subalternas tienen una mayor presencia y son múltiples las ocupaciones de los personajes: campesinos, trabajadores rurales, trabajadores desempleados, trabajadores jubilados, bolicheros y dueños de pequeños hoteles, agentes policiales, artistas, prostitutas, maestras, soldados del ejército, vagabundos, ladrones, camioneros, médicos, enfermeros, abogados, artesanos, músicos, proyectoristas, caciques y machis. Lo interesante es que, además, muchos de ellos se caracterizan por tener una relación informal, flexibilizada o temporal con el trabajo remunerado. Aquí, entonces, el trabajo deja de ser el elemento transformador (hacia mejor) del espacio patagónico en pos de la modernización capitalista y la construcción de la Nación. Y no es casual entonces que salvo excepciones -Guerreros y cautivas y La nave de los locos- nuestros protagonistas no dejarán, luego de su paso por allí, un territorio transformado. Sí es el espacio el que, en muchos casos, modifica o impacta en las subjetividades de los personajes, pero sus acciones ya no parecen tener el poder modificador del entorno (salvo de manera efímera como la protagonista de El viento se llevó lo qué... o momentánea como el equipo de David Bass en La película del rey o los héroes de Caballos Salvajes). Las relaciones entre los personajes a su vez también están atravesadas por la precariedad, fugacidad, crisis, incomunicación, fracasos o muertes. La Patagonia deja de ser la tierra promisoria o la naturaleza productiva para ser un espacio en donde la incertidumbre, la contingencia o la imprevisión signan las existencias de quienes la habitan, reemplazando las anteriores biografías transitadas como proyectos individuales o colectivos. 
Esta afirmación es, sin embargo, una generalización que no les cabe a aquellos personajes-sujetos que forman parte de los pueblos originarios de la región. ${ }^{11}$ En las películas en donde éstos tienen incidencia narrativa, particularmente en Gerónima, la relación de ella y sus hijos con el territorio es una relación de larga data, inmemorial. Más importante aún es que no aparece la dicotomía ser humano-naturaleza; el film da cuenta de una totalidad, de una relación de mutua correspondencia que se expresa en la forma de habitarlo, sentirlo, recorrerlo, añorarlo: Gerónima y sus hijos forman parte del territorio y éste es parte de ellos. En La nave de los locos el conflicto narrativo pasa precisamente por las diferentes concepciones y usos del espacio que tienen el pueblo mapuche por un lado y la "comunidad blanco-occidental” por otra. Aquí también las relaciones familiares y comunitarias del pueblo mapuche aparecen remontándose a tiempos antiguos, y los lazos entre ellos, con sus ancestros y con su territorio son fuertes, ya que es la condición de poder seguir existiendo como pueblo. Además, el film contrasta la transformación avasallante del espacio que emprende el empresario turístico, antagonista de la historia, con las actividades económicas (rurales y artesanales) de la comunidad que se presentan relacionándose armónicamente -aportando al bienestar comunitario- con la naturaleza y con los otros habitantes del territorio.

Retomando, a diferencia de un momento histórico anterior, en el período de 1986-2002 se diversifican los sujetos sociales encarnados en los personajes que habitan o transitan los mundos representados en los films analizados, dividiéndose entre quienes establecen relaciones inciertas, pasajeras y no transformadoras del espacio patagónico y quienes, al ser comunidades originarias, establecen una relación de mutua pertenencia con el mismo.

A excepción de las películas históricas y de la representación de los pueblos originarios el resto de los personajes-sujetos aparecen imposibilitados de

11 Sobre la omisión, justificación o denuncia de la expansión colonial en el territorio de los pueblos originarios en Patagonia en la narrativa argentina pueden consultarse, por ejemplo, la tesis ya citada de Gasel (2012) y Mellado (2015). Para un análisis de las representaciones de los pueblos originarios y las fronteras en el cine argentino puede consultarse: Rodríguez (2015). 
transformar su entorno, y proliferan en pantalla relaciones eventuales, precarias, efímeras, fortuitas o aleatorias. Sus itinerarios biográficos y espaciales no son transitados en términos de proyecto a futuro. ${ }^{12}$ A veces su llegada a la Patagonia obedece al fracaso de su proyecto de vida en otro lugar o a la casualidad, y cuando los tienen esos proyectos son a corto plazo, se desvían en el camino o fracasan. Muchos de ellos no establecen lazos con el resto de los habitantes del lugar, o sus vínculos comunitarios son débiles. Estas biografías signadas por la carencia o el fracaso para proyectar(se) permiten concebir a la incertidumbre como cronotopo identitario -tiempo entendido como la cuarta dimensión del espacio-, lo cual es un indicio sintomático de los cambios que el neoliberalismo globalizador produjo en las subjetividades contemporáneas. La pertinencia de la noción de cronotopo debe ser entendida en su relación con la de ficción, en tanto su puesta en diálogo permite explicar algo acerca de la relación de los textos fílmicos en nuestro caso- con la sociedad o con el contexto social. ${ }^{13}$

Algunos de los films también expresan esa mutación o "fragilización" de las identidades en la forma en que el territorio opera como una poderosa fuerza transformadora de la subjetividad de los personajes-sujetos (en La nave de los locos, El viento se llevó lo qué, Gerónima, Guerreros y cautivas, Flores amarillas

${ }^{12}$ Esto está en consonancia con lo planteado por Gonazlo Aguilar (2006) como característico del nuevo cine argentino: nunca habían sido tan omnipresentes los personajes por fuera de lo social (Aguilar 30). Éstos no son los rebeldes del cine político, aquellos oprimidos que actuaban transformando $-\mathrm{o}$ intentando transformar- las injustas relaciones que estructuran la sociedad. Tampoco son los personajes del típico cine costumbrista en que cada uno constituía un signo de la jerarquía social. Comienzan a aparecer personajes cuya historia desconocemos, sujetos de los que no se sabe de dónde vienen, pero tampoco a donde van. Son marginales, pero ya no es la marginalidad que porta una acción transformadora y heroica, sino que se revela a partir de personajes que simplemente exhiben su condición de excluidos y de prescindibles para la sociedad.

${ }^{13}$ Bajtín define al cronotopo como una conexión esencial de elementos espaciales y temporales. El concepto expresa el carácter indisoluble de la relación entre espacio y tiempo -el tiempo concebido como la cuarta dimensión del espacio-, facilita la percepción de los mismos como un todo inteligible y concreto y posibilita su asimilación en las producciones artísticas y literarias. En él el tiempo se condensa y se vuelve visible artísticamente, mientras que el espacio se intensifica y penetra en el movimiento del tiempo, la historia y el argumento. El tiempo penetra en el espacio y éste pasa a ser comprendido y medido a través del primero (Bajtín, 1989). Para el teórico ruso el cronotopo actúa como mediador de las valoraciones sociales, y a la vez enlaza las distintas esferas de la creatividad ideológica, lo que permite plantear que existe un cronotopo identitario que atraviesa el discurso social de una época determinada (Boria, 2010). 
en la ventana y Caballos salvajes). Arrolladora fuerza, buscada o no, que muchas veces se metaforiza en los textos fílmicos a través del movimiento del viento como potencia ingobernable. Así la construcción de los personajes y de las historias oscila contradictoriamente entre la historización de la región y los sujetos -en tanto la configuración identitaria es un proceso constante-, y cierta esencialización de lo "natural", el "salvajismo" o lo indomable. El viento también es una figura ambivalente que se interpreta como símbolo de movimiento-cambio continuo "que rearma al nuevo sujeto de una manera constante que no se detiene y siempre vuelve a comenzar" (Gasel 146), pero más generalmente como sinónimo de un territorio indómito.

\section{En búsqueda del tiempo perdido: entre la Patagonia epopéyica y la Patagonia rebelde}

Diferente es el imaginario que se plasma en Guerreros y cautivas ya que el mismo forma parte de un discurso residual que representaba a la región como epopéyica, porque justamente se narra la incorporación de la región a la nación y el proceso mismo de construcción de "lo" nacional. Por lo que este texto fílmico contiene todos los topoi de estas narrativas: la dicotomía civilización-barbarie, el sacrificio como condición sine qua non de la implementación del progreso, la heroicidad de hombres y mujeres, "criollos" y europeos, que actúan como agentes civilizadores, la hostilidad del paisaje que resalta el hacer de los nuevos habitantes, la frontera como espacio de conflicto, la escuela, la bandera y la literatura como elementos indicadores de la creación- imposición de una cultura e identidad nacional. Esta categorización general se complementa con el modelo fílmico que, concretamente para la cinematografía argentina, Ana Laura Lusnich denomina drama social-folclórico. Y dentro de éste su variante de ambientación histórica, donde lo que se prioriza es la reconstrucción material y fijación icónica -por lo que adquiere importancia la ambientación escenográfica-, para que las 
formas de tiempos pasados aparezcan con inmediatez a partir del poder de las imágenes (Lusnich 91). Aunque este modelo describe un corpus fílmico ubicado entre los años 1933 y 1956, podemos observar su influencia en algunos rasgos de Guerreros y cautivas que son importantes en tanto nos plantean cómo la historicidad de las formas fílmicas va construyendo determinadas ideologías de la representación del espacio patagónico. Es a través de este modelo que el desierto caracterizado por su amplitud, la adversidad climática y el carácter rústico del paisaje, y las posiciones adoptadas por los grupos humanos que lo pueblan o lo ambicionan (el "salvaje" asume el rol de oponente y es un elemento perturbador; las poblaciones y los establecimientos militares representan los primeros estadios de la civilización) van a construir un repertorio de imágenes iconográficas y simbólicas que erigen el espacio como metáfora política. ${ }^{14}$

Estas nociones predominan por sobre la mirada crítica que el film sostiene respecto de la apropiación de tierras por parte de la clase dominante. Aquí obviamente la incidencia de los personajes sobre el territorio y de este sobre ellos, es intensa porque justamente Guerreros y cautivas trata de la conversión del potencial, pero todavía bárbaro, espacio fronterizo en parte integrante de la nación argentina de "ascendencia" europea.

La otra excepción a las generalizaciones antes planteadas es la única otra película del corpus que pertenece a la categoría de ficción histórica. ${ }^{15}$ Nos referimos a Flores amarillas en la ventana, cuyo universo histórico se da en el marco de las huelgas y posterior masacre de trabajadores rurales de principios del siglo XX. Estos sucesos fueron dados a conocer tempranamente por José María Borrero en su libro La Patagonia Trágica y más tarde difundido a través de la

\footnotetext{
${ }^{14}$ Por ello en este modelo fílmico (y en el film analizado) el entorno no es neutro y descriptivo, sino que "asume un rol distintivo al entablar una relación directa con el programa narrativo de los sujetos. Se trata de entornos que acompañan, preanuncian, interrumpen o glosan las aventuras del héroe, y que se hacen presentes y artícipes a través de las coordenadas espaciales y temporales [...] Además...se trata de entornos cualificantes, ordenadores, simbólicos, en el sentido de que remiten a instancias políticas, ideológicas y culturales" (Lusnich 68).

${ }^{15}$ Recordemos que son aquellas películas que se colocan temporalmente en algún momento de la Historia o se basan en personajes reales pero su enfoque histórico no es riguroso ya que el pasado aquí es utilizado como marco referencial.
} 
investigación de Osvaldo Bayer en Los vengadores de la Patagonia Trágica. Y en 1974 a partir del film muy visto -tanto en la época de su estreno como inmediatamente luego de la última dictadura militar- y premiado La Patagonia Rebelde (Héctor Olivera, 1974), película con clara intención de reconstituir la historia rigurosamente, para lo cual contó con la asesoría de Bayer. En Flores ... el espacio también es dicotómico, pero a diferencia de la ideología subyacente en la oposición civilización- barbarie, la tensión se construye entre la posibilidad de ser un espacio en donde primen la libertad y la justicia en contraste con otro donde las clases dominantes quieren imponer mayor explotación y desigualdad, masacre mediante. El espacio es otra vez un campo de batalla en donde hay vencedores y vencidos; estos últimos son los que han desafiado el statu quo tanto a nivel laboral colectivo (los trabajadores) como a nivel social- "personal" (los amantes que desafían las convenciones clasistas de su entorno). ${ }^{16}$ Aquí comparten con el resto de las películas la imposibilidad de la transformación del espacio (si hay un cambio, lo es en el sentido de reforzar y profundizar el orden imperante). Al igual que en Guerreros y Cautivas el rol decisivo del Estado está representado a través del ejército, pero a diferencia de ésta, en la que dicha institución aparece promoviendo el cambio hacia mejor, en Flores amarillas...ostenta su estricta función represiva re-ordenando el entorno a su estado anterior (es decir a un situación previa a la firma del convenio de trabajadores rurales), masacre masiva mediante, y eliminando al héroe trágico de la película (el peón enamorado de la hija de los dueños de la estancia donde trabajaba). Se garantizan a nivel de la narración -a través de la trama principal y de la secundaria- los intereses de la clase dominante, y se reafirma que el territorio patagónico es mercancía y no está exento de su lógica. Este texto fílmico -al igual que La Patagonia rebelde- denuncia como "falaz" el discurso de "lo" nacional y la demarcación entre argentinos y extranjeros en tanto se exhibe como un discurso legitimador esgrimido para invalidar los reclamos locales de los trabajadores y ocultar la extranjería de los

${ }^{16}$ Como lo expresa Tzvi Tal las "representaciones del espacio geográfico expresan el poder social que las produce, las cambiantes condiciones de existencia y los conflictos sociales que motorizan esos cambios" (Tal 68). 
intereses que dominan y detentan grandes extensiones del territorio. Se continúa así, el imaginario de la Patagonia trágica que como bien señala Alejandro Gasel para la literatura -y se aplica a la textualidad de este film- se corporiza en la eliminación y diseminación de los cuerpos/alteridades masacrados por el espacio: $:^{17}$

Fosas anónimas, cuerpos sin reconocimiento, abandono y desatención del cuerpo exterminado tiende a marcarse como característica propia. [...] La cuestión del anarquista y el anarquismo como desaparición de un proyecto político cultural que se re concreta y realiza en la zona de la periferia también resulta característica del territorio. (Gasel 146)

\section{La Patagonia es un viaje}

Ángel Uranga dice que la "Patagonia comienza con un viaje" (2011), ya que gran parte de la tradición literaria que "construyó" la Patagonia asocia a la región con dicha experiencia. Los viajes y sus narraciones, fueron parte de los procesos políticos, económicos y culturales necesarios para la n(d)ominación del territorio por parte de las clases dominantes y la inclusión del mismo en la vasta modernización capitalista. Viajes de "descubrimiento", extrañamiento, búsqueda, exploración, nominación, eliminación de alteridades y sojuzgamiento, cuyas experiencias convertidas en narraciones configuraron/textualizaron parte de la

\footnotetext{
${ }^{17}$ Alejandro Gasel considera que "[t]ras la matanza de los obreros en las conocidas huelgas del '20 llevada adelante por el Estado argentino se puede trazar una nueva forma de pensar los imaginarios sobre la Patagonia Austral. Nuevos imaginarios que tienen un fuerte tono perlocutivo en la medida que son denuncialistas y reivindicativos y deben persuadir sobre los acontecimientos trágicos y hasta de genocidios que se realizan en estos territorios que son gobernados por un naciente Estado argentino. La escritura de Bayer marca una reconocible y fuerte inflexión respecto a esa inscripción de los viajeros al Estrecho de Magallanes, por un lado, y los proyectos del Estado Nacional que busca sus límites, se organiza y pedagógicamente difunde las maravillas de este territorio, por otro. La película [La] Patagonia Rebelde es el ícono, en el sentido peirciano, de lo que significa este acontecimiento histórico y esta inflexión" (Gasel 76).
} 
tradición historiográfica. ${ }^{18} \mathrm{Y}$ también de los mitos incorporados a los imaginarios que todavía producen una mediación efectiva en las percepciones y concepciones para mirar y decir la región. En el corpus analizado la relación viaje-Patagonia es resemantizada en numerosos casos y de forma diversa, en parte, porque los viajes que recorren nuestros films tienen disímiles motivos y adquieren, en su recorrido, distintos sentidos, a veces incluso, contrapuestos.

En Guerreros y cautivas el viaje vuelve a ser gesta fundacional que incluye, como tal, la historización de las re-nominaciones espaciales que implicó el re-poblamiento patagónico vía expansionismo estatal: al iniciarse la narración el pueblo se llama Trapalcó para, al final, adquirir el nombre del héroe “civilizador" del film, el Coronel Garay. Este cambio forma parte de uno de los ejes centrales de toda la narración de Guerreros y Cautivas y que nos permite adjetivar el traslado de la protagonista como un viaje identitario. Aquí la reconfiguración identitaria va en dos direcciones: el espacio se altera por la agencia de los sujetos y éstos son a su vez modificados por el espacio; a excepción de los pueblos originarios cuya identidad, bestial y desindividualizada, aparece como esencia inmutable. Salvo ellos, todos los "arribados" a Patagonia devienen en personas diferentes. La identidad nacional se construyó-inventó mediante un proceso histórico, admitirá el film, pero una vez concluido no hay lugar para la hibridación y mucho menos para la convivencia de culturas diferentes: la Nación argentina es "blanca” y viajó desde el Atlántico, afirma Guerreros y cautivas.

En otros films el viaje se inicia motivado por una ilusión. Lo interesante aquí es que, en todos los viajes de este tipo, las películas ponen en escena el mito de la Patagonia como tierra promisoria para luego deconstruirlo. Quienes llegan al Sur con la ilusión de concretar un film como en La película del rey, conseguir y permanecer en un empleo como en Mundo Grúa, vivir en un territorio sin guerras como en Flores amarillas en la ventana, escapar de los peligros y características de la vida urbana como en El viento se llevó lo qué; ya sea a nivel de la narración

${ }^{18}$ Son numerosos los estudios que analizan críticamente la literatura de viaje por la Patagonia, por citar algunos: Fernández Bravo (1999), Livon Grosman (2003), Torre (2010), Gattás Vargas (2017), López (2003). 
como de la puesta en escena esa ilusión nunca se cumple. Es decir que la Patagonia aparece como "un objeto de deseo" que las propias narraciones se encargan de imposibilitar. Los films, entonces, expresan indicialmente el tipo de experiencias que el ajuste estructural neoliberal va marcando en los cuerpos y las subjetividades de los personajes-sujetos: los caminos y proyectos truncos, las pérdidas reiteradas, la incertidumbre. Los personajes son impotentes ante el entorno que en general se les opone de manera impersonal o intangible (quizá la presencia invisible del viento metaforice esto). Las causas o motivos de los fracasos nunca se elucidan ni queda claro de dónde vienen ni quiénes son los responsables. La excepción es Flores amarillas... en la que claramente los antagonistas están corporizados por personajes concretos, los terratenientes respaldados por el Estado, que hacen primar los intereses de esa clase por sobre la de los trabajadores y los amantes rebelados. Así se escenifica la irreconciliable diferencia entre las clases sociales también en la periferia de la nación y del mundo, en donde adquiere ribetes trágicos.

La otra experiencia de viaje muy recurrente es la del escape, y esto nos remite a una asociación que es la noción de un mítico y genérico Sur, a la que ha abonado la literatura y el cine norteamericanos, en donde "el Sur" remite inequívocamente a la libertad de los personajes que atraviesan la frontera para dejar atrás una opresiva vida anterior, un posible castigo o iniciar una renovación espiritual. Esta noción también aparece en algunos de los textos fílmicos de este corpus en donde la Patagonia es el destino al que los personajes llegan escapando de conflictos familiares, laborales o bélicos, de unos perseguidores concretos, del ritmo y vicisitudes de la vida en las grandes ciudades, de la pobreza, de la vida prostibularia o de un pasado traumático. Por su pertenencia genérica al road movie, Caballos salvajes quizá sea el film que más estereotípica y explícitamente postule la idea del viaje de escape al sur como sinonimia de la libertad y el encuentro con otra forma de vida. ${ }^{19}$ Para que no queden dudas la canción que

\footnotetext{
19 También otras películas como La película del rey por ejemplo se inscriben en lo que Elina Tranchini denominó road movie patagónico, variante local del denominado road movie que tiene
} 
musicaliza una de las secuencias de viaje en la ruta versa: "Búsquenme, me encontrarán en el país de la libertad”. En Flores amarillas..., por ejemplo, el viaje no es puesto en escena, pero sí se enuncian recurrentemente los motivos de la llegada de todos los personajes, que escapan de la pobreza, de la guerra o de su “estigma” social. Los grandes espacios vacíos que se muestran a través de numerosos planos, están asociados a lo deshabitado como condición para una vida apacible hasta que el devenir de los eventos cambie la forma de habitar y percibir el entorno. El viaje como escape por hartazgo es el de Soledad, la protagonista de El viento se llevó lo qué, quien decide escaparse de su empleo de taxista en la gran ciudad, de sus ruidos, sus ritmos y sus riesgos, y la Patagonia surge como casual destino que resulta ser idealizadamente un lugar con características inversas a su lugar de origen: la calma permea tanto al espacio natural y como al social, fusionándolos.

La cuarta experiencia de viaje que aparece es la de búsqueda. A diferencia de los viajes de exploradores, cronistas, científicos y políticos de los siglos anteriores, las contemporáneas búsquedas de estos personajes particulares son modestas y no van asociadas a proyectos expansionistas ya sea estatales o de clase que conviertan a la Patagonia en espacio productivo/cristianizado/civilizado. Tampoco aparecen como búsquedas proyectadas en el tiempo o con gran

su origen en Estados Unidos. El primero es definido por Tranchini como "un género que combina elementos del road movie clásico con la filmación del mundo patagónico transpuesto al registro cinematográfico como temporalidad, como paisaje, y como marca enunciativa" (Tranchini 257), en el que aparecen "héroes escépticos y desafiantes, una cartografia hostil e inquietante, el gusto por el relato de viajes, el Sur como destino de inevitabilidad, juegos de empalmes y bifurcaciones de caminos que desconciertan, comienzos y finales conjeturales e imágenes de devastación y desasimiento" (Tranchini 269). Según la autora, este género ofrece una deconstrucción de la representación mítica del Sur: "Estos films desmontan las representaciones sobre la Patagonia ofrecidas por el cine de las décadas anteriores, y recrean una experiencia de la más cruda desapropiación, un mundo devastado, despojado, desmantelado, cuya vida transcurre lejos de la ciudad, la tecnología y el progreso y en que las formas del trabajo fueron eliminadas, [...] un mundo rural que parece perdido. El escenario central es [...] el camino hacia el Sur, que el protagonista recorre impulsado por una determinada creencia, o por su necesidad de escapar a las convenciones, o por su rebeldía y su anticonformismo, o por su ansia de marginalidad y desafío" (Tranchini 258). Las películas que la autora define y analiza como road movie patagónico son, a saber: La película del rey (1986), Una sombra ya pronto serás (1994), Caballos salvajes (1995), Invierno mala vida (1997), El camino (Javier Olivera, 2000), Historias mínimas (2002) y Bombón el perro (Carlos Sorín, 2004). 
planificación; aquí la prisa o la inmovilidad absoluta, la casualidad y el desvío forman parte de esas búsquedas erráticas e inciertas. Por ejemplo, en La película del rey actúa como motivación de un proyecto original, pero sus constantes vicisitudes y fracasos hacen de la improvisación un método para la concreción imposible de la película que están rodando.

Pero es sobre todo en las tres últimas películas del corpus donde esto se evidencia más claramente. En Mundo grúa la búsqueda es clara porque el objetivo es primordial: hallar empleo. No obstante, el protagonista debe adecuarse, sin mediar formación ni tiempo, a las nuevas reglas del juego de la oferta y la demanda de mano de obra: aprender en pocos días a manejar grúas, someterse a exámenes médicos, viajar allí donde aparezca la posibilidad de un puesto de trabajo, improvisar el manejo de otras máquinas, decidir entre el inseguro desenlace de la lucha colectiva lejos de su casa o la precaria supervivencia cerca de sus afectos. Nuevamente lo fortuito y lo incierto imprimen características particulares a la -otra vez- infructuosa búsqueda de este trabajador, que funciona como alegoría de toda una clase social que vivía en Argentina una de las situaciones más graves de su historia debido a los inéditos niveles de desempleo, que conllevaban altísimos grados de precarización y flexibilización laboral. En el film el fracaso del protagonista viene a poner en imágenes la desarticulación del imaginario de la Patagonia como tierra promisoria, ya que los motivos de su infortunio en Comodoro Rivadavia son los mismos que los de Buenos Aires: las formas que asume la lógica económica del sistema de organización social. De esta manera el film no cristaliza lo local, sino que lo inserta en la región, la nación y el mundo. Es decir, inscribe a la Patagonia en un espacio más amplio y en un tiempo histórico concreto en el que la situación de la clase obrera era por demás desfavorable. ${ }^{20}$

${ }^{20}$ Un análisis más extenso de este film conlleva necesariamente una interpretación sobre el modo de representación del trabajo y los trabajadores. Por un lado, desde las condiciones objetivas que enmarcan esa práctica, en este caso las políticas de ajuste neoliberal de privatización de empresas públicas y de reducción cuantitativa de la fuerza de trabajo empleada en el sector productivo, que llevaron a fines de la década del ' 90 a un índice de desempleo de casi $20 \%$. Y por otro -desde la perspectiva cotidiana que representa el film- el impacto en la subjetividad y las 
En Invierno mala vida la búsqueda vehiculiza la narración del film, pero puede interpretarse de las más diversas maneras ya que la poetización de lo real propicia la multiplicidad de interpretaciones espectatoriales. Por otro lado, la película misma metaforiza desde la construcción simbólica de su relato un mundo en decadencia sugerido a partir de las ruinas del pasado, la deshabit(u)ación, la inmovilidad y la pulsión escópica. Y su estructura fílmica abierta juega con la indistinción entre lo fantástico, lo imaginario y lo real. Entonces el núcleo de la trama, la búsqueda del vellocino de oro, puede metaforizar múltiples cuestiones. Por ejemplo, lo cuasi quimérico que resultaba concretar un largometraje en la Argentina de fines del siglo XX, o lo difícil que era para las clases subalternas conseguir y mantener un empleo, asociado esto último a la necesidad de aceptar tareas inadmisibles requeridas por dueños o jefes a fin de no ser despedidos. Como en Mundo grúa, en este film la historia comienza cuando el protagonista encuentra aquello que buscaba y el conflicto se desata cuando lo pierde. $\mathrm{Su}$ reemplazo exitoso por una falsa oveja dorada puede simbolizar la posibilidad de desquite de los sectores más castigados por las clases dominantes o la invitación al sostenimiento de las utopías como forma de resistencia. Con respecto a la búsqueda, si bien tiene un objetivo fantástico pero claro, es un tipo de búsqueda errática con desvíos deseados e indeseados. Está además mediada por engañosos relatos de la misma, por sueños, por accidentes y por la embriaguez constante del protagonista. Es una búsqueda en la que la casualidad prima por sobre la

consecuentes acciones de los millones de trabajadores que en todo el país sufrieron el ajuste estructural del neoliberalismo. Ya hemos definido al neoliberalismo como la realización de la hegemonía del capital financiero. Éste se impuso en nuestro país desde mediados de los '70, pero se expresó más nítidamente con el inicio del gobierno de Carlos S. Menem que produjo una concentración de la riqueza y una distribución de la pobreza. Esta concentración del capital se tradujo en una profunda alteración del estilo de vida y de las condiciones laborales de las relaciones sociales de la clase obrera. De todos los golpes el de mayor impacto fue el relacionado al empleo. De todo esto habla Mundo Grúa. Habla de la centralidad del trabajo precisamente porque no está. Pero esa ausencia no nos permite pensar en el fin de "la sociedad salarial", sino que es una ausencia que quiebra material y subjetivamente a millones de trabajadores y trabajadoras en el mundo, entre quienes sobreviven al desempleo y los que padecen el sobrempleo. De ahí que los amigos de Rulo lo consuelen cuando tiene que dejar todo para ir a trabajar a 2.000 kilómetros de distancia de su casa y su familia "Qué te quejás, por lo menos vas a tener laburo" (Extraído del film) 
causalidad, y quizá el imprevisto éxito del personaje sólo tenga por explicación la suerte (o la sospecha de que acaso también sea parte de un sueño).

En Historias mínimas se narran búsquedas a través de viajes a lugares cercanos en los que los objetos/objetivos son en apariencia insignificantes: un perro, una torta y un electrodoméstico. Sin embargo, esos objetos encarnan otras búsquedas intangibles, cuasi universales, sublimadas, como la del amor, la expiación o el reconocimiento. La dilatada extensión del espacio patagónico representa la autopercepción de esos sujetos históricos subalternizados (una mujer desempleada, un trabajador precarizado, un anciano abatido), que son "mínimos" en tanto han sido colocados en la periferia de un todo social que intenta convencerlos de su prescindencia. Ellos resisten la soledad y las carencias impuestas, a partir de la búsqueda de esos pequeños objetos que les permiten la esperanza. Por otro lado, la Patagonia es el espacio-lugar de los personajes y su viaje no es definitivo ni los transforma. La región patagónica se configura así, como un territorio cotidiano -aunque periférico- en donde la resistencia a la globalización neoliberal es asumida de manera individual e inconsciente, desarticulando el imaginario de lo desértico, pero proponiendo otro: el de un territorio incontaminado de conflictividad social explícita.

En estos viajes existen diferentes representaciones, algunas de ellas enfrentadas. Lo inaugural y la Patagonia como potencialidad deja paso a otro imaginario en el que - a veces- la región tiene una historicidad de larga data y se encuentra poblada, pero sus habitantes, vivencias y experiencias son vistos/representados como exóticas alteridades.

\section{Habitar la frontera: entre Patagonia for export y la Patagonia como umbral}

La otra noción que también ha sido profusa y prolongadamente asociada a la Patagonia es la de frontera, que aparece en múltiples acepciones y sentidos. La frontera constituyó un núcleo fuerte en la topografía mental del siglo XIX 
argentino y continúa siendo un núcleo irresuelto de la cultura nacional es, por un lado, un término polisémico y, por otro, su existencia concreta es experimentada de forma tangible y, a veces, trágica por los sujetos históricos. Las fronteras no refieren solo a los límites divisorios en términos territoriales, administrativos y políticos. Son fronteras temporales, culturales, simbólicas, linguiísticas, sociales y económicas por lo que puede inferirse que la noción de frontera además de ser colindante con otras nociones como lo son civilización y/o barbarie, y para el caso de Patagonia con el significante desierto, debe pensarse en plural y como construcción histórica cuya realidad e imaginarios se modifican conflictivamente con el tiempo.

En Guerreros y cautivas conviven en tensión dos de esas acepciones. Por un lado, presentará la frontera como lugar complejo de encuentros y desencuentros, de conflictos y negociaciones constantes entre diferentes culturas, conformando una cultura fronteriza en el sentido de que los sujetos de la misma se trastocan en el proceso de contacto. Sin embargo, finalmente se impondrá la noción más tradicional: la de frontera como límite, si bien móvil, en la que el avance de un espacio nacional -conformado exclusivamente a partir de lo blanco/occidental- elimina el otro espacio, el indígena, que aparece entonces como puro pasado.

La otra noción de frontera -y la que aparece más recurrentemente en nuestro corpus- es la de periferia en oposición al centro. La frontera pierde su complejidad al dejar de ser umbral, es decir unidad de espacio-tiempo de encuentro entre los sujetos cuyas tensiones y negociaciones permanentes (re)territorializan sus experiencias (Bajtín, 1989). Hay una insistencia en representar a la Patagonia -y homogeneizarla- como un espacio exclusivamente no urbano. Es decir que se construye a partir de lo que no es, y donde subyace una fuerte identificación dicotómica: urbano/complejo/variado frente a rural/bucólico/uniforme. Al uniformizar la forma de habitar el espacio geográfico y cultural necesariamente se le restan características sociopolíticas e históricas conflictivas. Lo no urbano viene asociado a un imaginario sobre Patagonia en el 
que predomina la (pura) naturaleza por sobre las tramas siempre en conflictivo movimiento de la cultura, la sociedad y la política. De esta manera la región es desplazada de la historia y se

constituye como una cronotopía geofísica con propiedades determinantes para identidades que encontrarían en las particulares condiciones terrígenas su razón de ser. Es decir, habría un modo de ser patagónico, y ese modo estaría fijado por las condiciones naturales del territorio. (Mellado 26)

A su vez de esta idea de frontera como ex-centricidad o periferia se desprenden dos representaciones, una de las cuales se erige como imagen responsiva de la idea anterior. ${ }^{21}$ La Patagonia se propone en algunos films como marginalidad alegórica de una amplia región como es Latinoamérica o todos los países del hemisferio sur en cuanto comparten su condición de países capitalistas dependientes. Por ejemplo, en La película del rey el espacio patagónico -desde sus mesetas desoladas hasta el silencioso orfanato- metaforiza la devastación socio-económica, política, cultural y estética impuesta por las dictaduras latinoamericanas. Las vacías superficies de la Patagonia no representan la falta de historia, la vacancia, la deshabitación o la posibilidad, sino que contrariamente se señalan como pruebas del arrasamiento que causaron aquellos procesos dictatoriales. La Patagonia como frontera, entonces, es expresión metonímica del lugar asignado a Latinoamérica -mediante un proceso histórico concreto a través del cual las clases dominantes impusieron a sangre y fuego la hegemonía del capital financiero-, en el marco de la desigual distribución de trabajo, riqueza y poder en la que el mundo se divide.

La noción de frontera que emerge en El viento se llevó lo qué contiene, no sin tensión, los dos análisis anteriores. En dicho texto fílmico el espacio se

${ }^{21}$ Con este término se alude a que "toda comprensión real y total tiene un carácter de respuesta activa y no es sino una fase inicial y preparativa de la respuesta (cualquiera que sea su forma)" (Bajtín 258) 
configura como una periférica alteridad radical respecto del centro urbano del que proviene la protagonista. Este centro es representado ambivalentemente ya que por un lado es peligroso y represivo y al mismo tiempo generador exclusivo de arte, conocimiento, información, en una palabra, de cultura, que llega a la frontera/margen de manera retrasada, distorsionada e incompleta. Como en $\mathrm{La}$ película del rey, también supone alegóricamente una cronotopía argentina, pero aquí -quizá con cierta mirada colonial- es pensada como un espacio marginalizado por la concentración geopolítica del poder, la información y la cultura, que le deja a la periferia la única posibilidad de re-crear la suya a partir de los desechos del centro.

Por otro lado "sabemos que atravesamos fronteras, pero también sabemos que las fronteras nos atraviesan" (Camblong 127). En algunos films lo fronterizo metaforiza el proceso de ajuste estructural neoliberal que imprime en la configuración identitaria de los personajes-sujetos una subjetividad border. Es en Invierno mala vida donde quizá estas subjetividades -zombies como las denomina Gonzalo Aguilar- se expresan en todas sus dimensiones: poéticas, metafóricas, históricas, individuales y colectivas. Pero también pensemos en todos los personajes de La película del rey y de El viento se llevó lo qué; en las formas de experienciar el espacio de Gerónima y su familia en la película que lleva su nombre; en el pueblo mapuche representado en La nave de los locos; en la transformaciones de los protagonistas de Guerreros y cautivas y Flores amarillas en la ventana; en las resignaciones y resistencias de los personajes de Historias mínimas; en los obreros que trabajan junto al protagonista de Mundo Grúa en Comodoro Rivadavia; en los personajes secundarios de Caballos salvajes: son los excéntricos, los fracasados o los excluidos de los beneficios del orden, la población 'sobrante' para el gran capital concentrado. En ellos también aparece esa "estancia fronteriza" de la que habla Ana Camblong en la que lo paradójico, la aporía, en fin, el umbral, es la forma característica de habitar/ser en la frontera: 
Nuestra estancia movediza, esquiva y excéntrica instalada en el deslinde, habitando el borde, resulta 'irrelevante' o, lo que es lo mismo: insignificante...La 'estancia entre' instaura un espacio tercero que deslinda lo uno y lo otro, los mantiene en fricción, los mezcla, los confunde y los pone en crisis. [...] [L]o paradojal está inextricablemente enroscado en los regímenes vigentes, en las estrategias políticas y las distribuciones económicas. No hay paradoja porque sí, porque exista un lugar llamado frontera donde se crían o proliferan paradojas/aporías como si fueran parte de la flora o del paisaje. No podríamos, no deberíamos buscar o enunciar leyes universales de la discontinuidad y los confines. Hay historia, hay acontecimiento y hay responsabilidad política en los avatares aporéticos del margen extremo. (Camblong 127-131)

Por otro lado, en la posmodernidad -entendida como dominante cultural del capitalismo tardío (Jameson 1995, 2012)- la cultura y el arte han dado un salto cualitativo respecto de su condición de mercancía para el capital, no sólo a través de la estetización de los bienes de consumo sino también de la espectacularización de lo cotidiano y de la simulación o des-realización de lo real. No es casual, entonces, que en los films analizados la Patagonia -en tanto con-fin o margen- sea transitada por artistas que intentan real-izar la cultura, pero cuyos intentos no encuentran lugar en estas coordenadas cronotópicas (como el cineasta de La película del rey y su productor, el actor francés en decadencia de El viento se llevó lo qué e incluso el músico que conoció el éxito en el pasado, pero ahora hace “changas, siempre changas"22 de Mundo grúa).

En definitiva, la frontera también aparece como un proceso de subjetivación -referido a los personajes individuales, pero como miembros de las clases subalternizadas- mediante el cual a los personajes-sujetos se los ha despojado de derechos y de certezas desdibujándoseles su "horizonte de expectativas", entendido como el encuentro entre la esperanza y la memoria

\footnotetext{
${ }^{22}$ Extraído del film.
} 
(Koselleck 1993). Esto se ve puntualizado claramente en Gerónima, film cuyo fuerte tono denuncialista no alcanza sólo a la diégesis o al contenido de lo narrado sino también a su estructura y estrategias estilísticas, las que implican una reflexión respecto de las formas en que esas denuncias pueden dar cuenta de las voces-miradas, en fin, culturas, violentamente silenciadas. En este film la estructura particular del guión, el género de docuficción y la mixtura de materiales visuales y sonoros le permiten al equipo realizador cuestionar las formas de unas prácticas -en este caso estatales- y unos discursos -el discurso médico occidental- para señalar el despojo histórico continuado al que fueron sometidos los pueblos originarios de NuestraAmérica. ${ }^{23}$ En el desenlace del texto fílmico la subjetividad de Gerónima violentada por el hombre, el Estado y la ciencia médica traspasa con ímpetu la frontera de "la" racionalidad para -en su enajenación total-, cuestionar "el dominio consolidado y omnímodo de la razón”. Aquí el espacio está historizado en tanto la construcción de la región es permanente, ya que depende de las prácticas que realizan las personas entre sí y sobre el paisaje -en un proceso contradictorio-. Pero, a su vez, el film entiende que también las representaciones, las miradas y las nociones que se construyen sobre ese espacio tienen consecuencias prácticas y, por ende, siempre forman parte de su construcción. Por ello, el plano con el que se inicia el film es un campo largo en el que se observa un paisaje vacío (con fuerte y sonoro viento) y

23 La docuficción debe entenderse a la luz de las características de la sociedad y la cultura contemporáneas, se presenta en general "como un programa de regeneración estético que reacciona tanto al agotamiento de formas representativas y perceptivas como ficcionales. Por un lado, permite proseguir con la tradición posmoderna del juego metaficcional (aunque bajo pronósticos diferentes), por otro, al ocuparse de temas relevantes para la sociedad y la política, indica el camino hacia afuera del 'universo textual' posmoderno" (Tschilschke y Schmelzer 20). Atendiendo al contexto no solo mundial sino de la pos-dictadura argentina creemos que esta definición permite pensar en las intenciones (tanto conscientes e inconscientes) del equipo realizador respecto del carácter de denuncia y reflexividad, a un mismo tiempo, que el film contiene. Al igual que La película del rey, Gerónima se ubica dentro de un conjunto más amplio de producciones artísticas emergidas en el campo cultural argentino de la pos-dictadura que surgen para disputar un espacio de significación al discurso monológico dominante, constituyéndose como palabras responsivas a la uniformidad impuesta por las políticas implementadas entonces (Juliano, 2010). Esta caracterización se halla en los rasgos formales del film, advertidas por Ana Juliano para un corpus cultural más amplio: a) texto autorreflexivo; b) hibridación de las fronteras genéricas; c) evocación de la "totalidad" a partir de fragmento, d) problematización de la representación y e) cuestionamiento del discurso historiográfico. 
el travelling horizontal va sumando porciones de ese mismo paisaje desolado. Pero la imagen siguiente constituye un primer plano del rostro de un oficial del ejército argentino del siglo XIX observando ese espacio. El plano con el que se inicia el film -el del paisaje- por ser el primero parece adherir a la idea de la Patagonia como "espacio vacío", pero el plano que le sigue da cuenta de que lo "vacío" está contenido en la mirada del representante del estado argentino. Es decir, el proceso de conquista vació representacionalmente un espacio para luego vaciarlo materialmente de aquellos sujetos y formas culturales que no servían al proyecto político económico de la nación argentina. El film se abstiene entonces de formular una proposición de la región en tanto lo que postula es que se trata de una construcción histórica en la que cada cultura la vive, la entiende, la rememora y la añora según sus particularidades. Además, parte de la eficacia de la denuncia que el film expresa está en su adhesión a la idea de que existe una política de la mirada: "así como no hay lecturas inocentes [...] tampoco hay formas 'puras' de la mirada que puedan pretender no sé qué ingenuidad incontaminada por el barro y la sangre de la historia" (Grüner, El sitio 13).

Retomando, entonces, la frontera en el corpus analizado "se trata no sólo de un hábitat, sino también de un modo de habitar. Los habitantes del borde se habitúan a los desbordes y a los contrasentidos. Se podría decir que el habitante de la frontera es un habitué de la entropía" (Camblong 131).

Por último, en otros films la Patagonia como oposición al centro aparece en toda su ex-centricidad, en el sentido de un confín que extrema su particularidad para proveerlo, exotismo mediante, de una cualidad de lugar único. Si bien los textos son disímiles, muchos de ellos le imprimen una asociación de espectacularidad al paisaje -en tanto espacio para la contemplación-, exagerado en su gigantismo, que claramente abona el discurso turístico de la Patagonia for export. Operación que tiene implicancias mucho más profundas que la de simple convite mercantil a foráneos de distintas latitudes para que conozcan y compren (en) la región. Ya que -como señalamos anteriormente- esas características 
supuestamente excepcionales alcanzan, dicen los textos, a los habitantes patagónicos al ser representados como

alteridades a través del exotismo, lo que aseguraría su comerciabilidad, y la neutralización de los rasgos sociopolíticos e históricos conflictivos, a través de la uniformización de dicho exotismo. Estos dispositivos, vinculados con lo que Žižek llama el racismo posmoderno, muestran la propia contradicción del proyecto ideológico liberal-democrático que 'tolera' al otro nominal y folklórico, pero desconoce y descalifica a los otros reales. [...] La folclorización de la Patagonia argentina se implanta, entre otros procedimientos simbólicos, a través de la reproducción de un imaginario que la propone como pura naturaleza. (Mellado 126)

Si bien la película que contiene y difunde inequívocamente dicho imaginario es Caballos salvajes, esta exotización homogeneizante se despliega también, aunque en menor medida, en El viento se llevó lo qué, Historias mínimas y La nave de los locos.

Todos los films, aunque por motivos y de maneras divergentes, exhiben las marcas del momento histórico en el que fueron producidos. Por un lado, las características distintivas que adquirió la globalización neoliberal en la formación económico-social argentina permearon los modos de producción de los films -ya sea por su dificultad, ya sea por sus innovaciones tecnológicas, ya sea por las incorporaciones de otras formas de producción y de lenguajes que diversificaron el discurso cinematográfico-. Las cada vez mayores dificultades de acceso al financiamiento, a veces imposible para los noveles cineastas, promovieron la incursión en maneras alternativas de concreción de largometrajes como por ejemplo las cooperativas, los extensísimos tiempos de rodaje y la búsqueda de financiamiento privado por nuevos circuitos (como los festivales internacionales o los canales de televisión). Estos modos de producción alternativos o novedosos, terminaron por reflejarse en una poética determinada, y dan cuenta de los intensos 
cambios económicos, políticos, sociales, culturales y tecnológicos de la globalización neoliberal que impactaron directamente en las prácticas, los productores y los resultados de la realización cinematográfica en Argentina. ${ }^{24}$ Las marcas de esos procesos -el social general y el de producción particular- se exhiben indicialmente en la textualidad de los films (por ejemplo, el modo alternativo de tiempos extensos y concepción no industrial se observa en Gerónima, Invierno mala vida y Mundo grúa, y en menor medida en los dos films de Sorín).

Por otro lado, ya hemos mencionado el desplazamiento de la representación de Patagonia desde discursos didactizantes que la promueven como baluarte del proyecto nacional o que la asocian al vacío como espacio en el que todo está por hacerse, en el sentido de potencialidad productiva. En el período que abarca nuestra indagación, hemos reconocido una mayor pluralidad de textos en cuanto a que sus postulados estético-ideológicos resemantizan otros imaginarios asociados al territorio. Algunos de ellos activan una representación de Patagonia for export a partir de dotarla de una naturaleza exótica o una

${ }^{24}$ Por ejemplo, al momento de estrenarse Invierno mala vida Cramer reflexionaba: "La realidad es que si querés hacer una primera película, no se puede hacer dentro de la normalidad. Me refiero a que no hay un mecanismo establecido. Cada persona que hizo un largo en los últimos años fue porque encontró una excepción. Incluso hasta los que han ganado concursos del INCAA son excepciones: como los telefilms Pizza, Birra, Faso y 24 horas. Y son los únicos concursos de los últimos seis años. Desde que yo tengo memoria no hubo otros" [...] "Si hay un mercado tenés que matarte para conseguir la plata para filmar, hasta que consigas a alguien que lo haga por vos. A mí no me causa gracia salir a buscar plata, pero hasta que consiga a un productor, no me queda otra. Me parece que ése es el problema de hacer una primera película: tener que hacerla. Yo no conozco productores en la Argentina que se dediquen a buscar dinero." (Cramer citado por Mendivil). Otro ejemplo es el Carlos Sorín que, aprovechando las últimas innovaciones tecnológicas para filmar Historias mínimas, pudo lograr una importante reducción de la cantidad de personas del equipo de producción y una mayor flexibilidad en el proceso de filmación. Sorín accedió a un financiamiento parcial del INCAA pero, con la devaluación del peso argentino del año siguiente, le representó un porcentaje exiguo respecto de la totalidad del presupuesto necesario. Al igual que Roberto, el viajante de comercio de Historias mínimas, Sorín plantea que este cine que tiene capacidad de improvisación y de aprovechamiento de pocos recursos no sólo es posible, sino que es apreciado en los circuitos y mercados cinematográficos europeos. Esto decía el cineasta en mayo del 2002: "Creo que ahora el mercado externo va a ser decisivo para este cine. Porque, en tanto pueda producirse con costos muy acotados... Quizá la cosa pasa por asociarse. [...] Además, creo que va a ser difícil contar con apoyo del Instituto, con subsidios. En un país donde falta insulina, o no hay leche en los comedores escolares, pensar que va a haber plata para el cine es ilusorio. Es decir que los que hacemos cine, vamos a tener que arreglarnos por nuestra cuenta" (Sorín citado en Montesoro). 
inmensidad enigmática para la contemplación o la aventura transitorias de viajeros-consumidores contemporáneos. Tácitamente el territorio "se presenta como un objeto de mercado para ser vendido a un público (norteamericano y europeo) que compraría ese producto for export" (Gasel 146). Este corrimiento expresa y difunde a nivel simbólico uno de los cambios que el neoliberalismo produjo en el territorio en el plano económico-materia. ${ }^{25}$ Es decir que, si sostenemos que las prácticas culturales pueden responder a discursos dominantes, emergentes o residuales, y si pensamos en la funcionalidad que la mutación epocal neoliberal le designó a la región patagónica, podemos concluir que esta representación forma parte de las prácticas culturales dominantes de la época.

Quizá esto explique -en parte- la recurrencia de otras imágenes que, si bien no son equivalentes, están en afinidad con el imaginario turístico. Nos referimos a la Patagonia uniformemente representada como no urbana. La utilización de tales términos busca subrayar la construcción de la región a partir de lo que no es: la ciudad. Si no hemos utilizado la palabra "campo" o "rural" es porque los elementos, o más específicamente los signos icónicos, ${ }^{26}$ no describen un espacio que dé cuenta de un tipo de vida específico. El "mundo rural" con todas sus particularidades, problemáticas sociales, ambientales y económicas y sus diversidades subregionales, parece no ser perceptible para los equipos

${ }^{25}$ Estos cambios durante el período de referencia pueden resumirse de la siguiente manera: se observa una mutación hacia una estructura económica dominada directamente por el capital financiero trasnacional que controla los enclaves de gran capital (extracción y depredación de recursos naturales como petróleo, pesca, hierro, aluminio, etc.). Respecto de los enclaves, se constata también la retirada del estado en tanto planificador (polos de desarrollo, promociones industriales) ya que no resulta rentable para las empresas privadas. Se desarrolla una estructura depredadora y parasitaria, basada en el extractivismo o, mejor dicho, en el saqueo de los recursos naturales, en el cual los problemas mal llamados "naturales" como la desertificación de la meseta, la escasez de agua potable o la casi extinción de algunas especies fundamentales para la pesca son resultado de las actuales formas del sistema económico social imperante. Se produce un nuevo marco social y de relaciones de fuerza caracterizado por una mayor explotación de los obreros ocupados, cierre de fábricas, un aumento del porcentaje de personas que no participan en actividades productivas, y una fuerte centralización económica de los recursos que pauperiza a las clases subalternas y angosta la clase dominante (Gatica, López, Monedero y Pérez Álvarez 85).

${ }^{26}$ En términos generales, en un film alude al conjunto de los elementos no lingüísticos. "La toma aísla un elemento para ponerlo de manifiesto y, al hacerlo, constituye en realidad un signo" (Sorlin 47). 
realizadores de los films analizados (las excepciones a esto son Gerónima y Flores amarillas en la ventana, aunque ello obedece a su condición de relato histórico de un conflicto rural). ${ }^{27}$ Las imágenes más recurrentes son las de pequeñas localidades escasamente pobladas (excepto Mundo grúa que insinúa en muy pocos trazos la ciudad de Comodoro Rivadavia) y las de lugares de paso apostados a lo largo de caminos y rutas. Predomina una mirada hacia/sobre el espacio como distancia social, en términos de lo planteado por Williams en $E l$ campo y la ciudad (2001), es decir: una mirada afectiva y distanciada a la vez, que asume el punto de vista de un observador ocioso, que está de paso y se permite mantener distancia y observar el espacio como un ámbito que existe más allá de las desiguales relaciones sociales en las que hombres y mujeres producen la vida y la cultura.

Esta no urbanidad a su vez suele estar acompañada de otra cualificación: la de lo antiguo. En esto podemos leer vestigios residuales de una representación asociada a cierta idealización de la Patagonia como un lugar otro -donde la mismidad/normalidad sería la caótica gran ciudad moderna- al que la modernidad civilizatoria no ha alcanzado en su totalidad o avanza a ritmos más pausados. La naturaleza parece predominar sobre la cultura, con lo que la Patagonia no sólo es otro lugar, sino que también parece ser un "viaje en el tiempo". El gigantismo naturalista ya no está ligado al imaginario del territorio como castigo, pero contiene suficiente hostilidad (aunque sea por la carencia de comodidades) y rusticidad como para que la sola llegada o desplazamiento de los sujetos en el territorio impliquen una aventura. Imágenes/nociones que indirectamente constituyen eficaces complementos de la representación turística ya mencionada.

En otros films (o paradojalmente en tensión dentro de un mismo film) las imágenes de inmensidad, infinitud o espacio vacío son resemantizadas en clave

${ }^{27}$ En las películas del período clásico el campo es representado profusa y diversamente en tanto allí el espacio es metonímico de la Nación -en singular y si conflictos internos- y se expresan cinematográficamente la promoción del ordenamiento social y, por otro lado, también se representa en el espacio la idea de progreso y modernización en los términos del modelo agroexportador. Al respecto puede consultarse, por ejemplo: Marrone y Moyano Walker (2001) y el ya citado Lusnich (2007). 
alegórica para dar cuenta de una cronotopía del despojo y de la enajenación material y subjetiva. Aquí el espacio no es un paisaje naturalizado sin agenciamiento humano, tampoco es sinónimo de una naturaleza sin gente o una celebración posmoderna de la diferencia sino una metáfora de lo que el proceso de ajuste neoliberal nos legó tanto en términos económicos y sociales -materialescomo en sus manifestaciones culturales y simbólicas.

\section{Cronotopía del despojo (o Conclusiones provisorias).}

Hemos llegado al final de este itinerario, que no solamente es parcial, sino que fue recorrido como uno de los caminos posibles para comprender la historia reciente del "sur del Sur" desde las representaciones que sobre ella produjo el cine argentino entre los años 1986-2002. Entendiendo al cine como parte integrante de la cultura de la cual procede, es decir como uno de los elementos constitutivos de las relaciones sociales, e inscribiéndonos dentro de lo que Nelly Richard denomina "materialismo crítico de la imagen y la palabra" (Richard 37). La Patagonia puede pensarse entonces como el "paisaje después de una derrota" que tan acertadamente describía el texto del historiador Adolfo Gilly (1994) para pensar las características de la historia reciente de la región latinoamericana.

Recapitulemos: por una lado advertimos la puesta en escena de la labilidad de los lazos sociales o su fragmentación; los proyectos empequeñecidos, fracasados o la falta misma de proyectos; el desempleo o la precarización laboral; la apropiación del territorio por la fuerza y los intentos de imposición de una cultura sobre otra; y la proliferación de sujetos subalternizados en la pantalla (por ejemplo mayor presencia de los pueblos originarios, ahora corridos de su representación negativa para ubicarlos en el otro polo de la dicotomía). Además, avistamos la falta de épica y de discursos didactizantes; la devastación de las subjetividades; los relatos ex-céntricos, fragmentarios, autorreflexivos; la poetización/alegorización de lo real y la profusión de intertextualidades; la 
representación problematizada; el cuestionamiento sobre la mirada y la evidenciación de la mediación lingüística de los films. Todo ello demuestra cabalmente cómo las mutaciones de las condiciones sociohistóricas modifican los regímenes de visibilidad. Y a su vez revalidan que las permanencias y cambios de la configuración socio-económica e identitaria de una región determinada pueden ser percibidos y analizados desde la textualidad fílmica como producto(re)s de su época.

Nuestra indagación fue transitada con una mirada no regionalista pero sí situada, desde la cual observamos nuestro objeto de estudio. Para ello fue necesario nutrirnos de préstamos y resignificaciones transdisciplinares, un saber de "otro modo", en términos de Zulma Palermo, que resista a las pretensiones excluyentes (universalizantes o globalizadoras) de los lugares de producción de conocimiento. Se trata de sostener la posibilidad de "cruzar la reflexión estética sobre la problemática significante de los lenguajes artísticos con la urgencia de una sostenida crítica a la hegemonía neoliberal y con la apuesta de la imaginación a diseñar nuevas fuerzas de emancipación subjetiva" (Richard 10).

A partir del análisis de las relaciones entre el cine y la sociedad es posible conocer no sólo la siempre constante des/re/configuración identitaria de los territorios, en este caso la región patagónica, sino también abonar a la puesta en crisis de las representaciones hegemónicas como momento ineludible de la constitución de otros imaginarios y otras memorias necesarias para la construcción alternativa de nuevas formas de organización social.

\section{Bibliografía}

Aguilar, Gonzalo. Otros mundos. Un ensayo sobre el nuevo cine argentino, Buenos Aires: Santiago Arcos, 2006. 
Álvaro Fernández Bravo. Literatura y frontera. Procesos de territorialización en las culturas argentina y chilena del siglo XIX, Buenos Aires:

Sudamericana/Universidad de San Andrés, 1999.

Bajtín, Mijaíl. Estética de la creación verbal. Buenos Aires: Siglo XXI, 2011. . Teoría y estética de la novela. Barcelona: Taurus, 1989.

Bandieri, Susana "La Patagonia en clave regional: un camino posible para una historiografía renovada". "La Historia Regional en la Argentina. Sus aportes y desafíos para el futuro", Solis Carnicer, María del Mar, compiladora. Folia, 24,Resistencia, (2015). http://www.scielo.org.ar/scielo.php?script=s ci_arttext\&pid=S0325-82382015000200010\&lng=es\&nrm=iso. $15 \mathrm{de}$ diciembre de 2017.

Bandieri, Susana. "La dimensión regional como alternativa analítica para pensar otros espacios y nuevas periodizaciones". Las escalas de la historia comparada. Tomo II. Empresas y empresarios. La cuestión regional, Susana Bandieri, Graciela Blanco y Mónica Blanco, coordinadoras. Buenos Aires-Madrid: Miño-Avila, 2008. 311 - 333.

. "La Patagonia: mitos y realidades de un espacio social heterogéneo." La Historia Económica Argentina en la encrucijada: Balances y perspectivas, Juan Gelman, compilador. Buenos Aires: Asociación Argentina de Historia Económica-Prometeo Libros, 2006. 389 - 410.

Historia de la Patagonia, Buenos Aires: Sudamericana, 2005.

Boria, Adriana. "Cronotopías y mujeres: ficciones identitarias". DeSignis:

Tiempo, espacio e identidades 15 (2010): 63-73.

Camblong, Ana María. "Habitar la frontera". DeSignis: Fronteras 13 (2009): 124139.

Escobar, Paz. "Cine e historia: la Patagonia en imágenes (1936-1976)". XI Jornadas Interescuelas/Departamentos de Historia, Facultad de Filosofía y Letras, Universidad Nacional de Tucumán, (2007). ISBN 978-950-554-5407 (formato electrónico).

. "Escenas de la Patagonia neoliberal: las representaciones de las actividades económicas en películas argentinas filmadas la región (1985-2006)”.

Revista Estudios del ISHiR Vol. 4, 8 (2014): 118-129. http://www.revista.ishirconicet.gov.ar/ojs/index.php/revistaISHIR/issue/view/33 . Cine e historia: la Patagonia en imágenes (1936-1976), Trelew: Jornada, 2011.

Gasel, Alejandro. De cuerpos y territorios. Itinerarios de la Patagonia Austral en la narrativa argentina reciente (1982-2008) Ensenada: Universidad Nacional de La Plata. Facultad de Humanidades y Ciencias de la Educación, 2012. http://www.memoria.fahce.unlp.edu.ar/tesis/te.305/te.305.pdf 20 de abril de 2017.

Gatica, Mónica y otros . Patagonia: desarrollo y neoliberalismo, Buenos Aires: Imago Mundi, 2005

Gattás Vargas, Maia. "Un cine-monstruo para un territorio monstruoso. Un análisis de dos audiovisuales sobre la Patagonia chilena”. La Fuga, 20, 
CATEDRAL TOMADA: Revista de crítica literaria latinoamericana / Journal of Latin American Literary Criticism El sur del Sur: cronotopías identitarias de la Patagonia en el cine argentino contemporáneo.

(2017) http://www.lafuga.cl/un-cine-monstruo-para-un-territoriomonstruoso/849 15 de diciembre 2017.

Gilly, Adolfo (1994) "Paisaje después de una derrota: Fragmentación y resocialización de las demandas y los movimientos".: El cielo por asalto, año III, no 6, verano (1993-1994). 37-45.

Gilly, Adolfo, Raquel Gutiérrez y Rhina Roux. “América Latina: mutación epocal y mundos de la vida." Neoliberalismo y sectores dominantes. Tendencias globales y experiencias nacionales, Eduardo Basualdo, compilador. Buenos Aires: CLACSO, 2006. 103-119.

http://bibliotecavirtual.clacso.org.ar/clacso/gt/20101101023845/basualdo.pd f 17 de abril de 2017

Grüner, Eduardo. "Foucault: Una política de la interpretación”. Topos \& Tropos 3, (2005). http://www.toposytropos.com.ar/N3/pdf/gruner.pdf 8 de abril de 2016.

. El sitio de la mirada. Secretos de la imagen y silencios del arte, Buenos Aires: Norma, 2001.

Jameson, Fredric. El postmodernismo revisado, Madrid: Abada, 2012. . La estética geopolítica. Cine y espacio en el sistema mundial, Barcelona: Paidós, 1995.

Jodelet, Denise. "La representación social: fenómenos, conceptos y teoría". Psicología Social II. Pensamiento y vida social. Psicología social y problemas sociales, Moscovisi, Serge, compilador. Barcelona-Buenos Aires- México: Paidós, 1984.

Juliano, Ana Verónica. "Notas a propósito de La película del rey (1986) de Carlos Sorín". Espéculo. Revista de estudios literarios 45, Universidad Complutense de Madrid, (2010) https://pendientedemigracion.ucm.es/info/especulo/numero45/reysorin.html 28 de abril de 2017.

Koselleck, Reinhart. Futuro Pasado. Para una semántica de los tiempos históricos. España: Paidós, 1993.

Kriger, Clara. Cine y peronismo: el estado en escena. Buenos Aires: Siglo Veintiuno, 2009.

Lefebvre, Henri. La presencia y la ausencia. Contribución a la teoría de las representaciones, México: FCE, 2006.

Levinson, Andrés. Cine en el país del viento. Antártida y Patagonia en el cine argentino de los primeros tiempos. Viedma: Fondo Editorial Rionegrino, 2011.

Livon-Grosman, Ernesto. Geografías imaginarias. El relato de viaje y la construcción del espacio patagónico, Rosario: Beatriz Viterbo, 2003.

López, Susana. Representaciones de la Patagonia. Colonos, científicos y políticos (1870-1914), La Plata: Al Margen, 2003.

Lusnich, Ana Laura. El drama social-folclórico. El universo rural en el cine argentino, Buenos Aires: Biblos, 2007. 
Marrone, Irene y Mercedes Moyano Walker. "Imaginarios contrapuestos en la filmografía del agro pampeano argentino". Mundo Agrario, 2. 3, (2001): 120 http://www.mundoagrario.unlp.edu.ar/

Mellado, Luciana. Cartografías literarias de la Patagonia en la narrativa argentina de los noventa. Rawson: Secretaría de Cultura de la Provincia de Chubut, 2015.

Mendivil, Pablo. "Pura lana". Página 12. Suplemento Radar. 22 de agosto de 1999. http://www.pagina12.com.ar/1999/suple/radar/99-08/99-0822/nota3.htm 15 de diciembre de 2017.

Montesoro, Julia. “Carlos Sorín, con el corazón en el Sur”. La Nación. 09 de mayo de 2002. http://www.lanacion.com.ar/395000-carlos-sorin-con-elcorazon-en-el-sur 17 de abril de 2015.

Palermo, Zulma. "Historiografía, literatura y región." Silabario. Revista de Estudios y Ensayos Geoculturales, I.1, noviembre, (1998): 61-74.

Pérez Álvarez, Gonzalo. Patagonia. Conflictividad social y neoliberalismo. El noreste del Chubut (1990-2005), Buenos Aires: Imago Mundi, 2013.

Richard, Nelly. Fracturas de la memoria. Arte y pensamiento crítico, Buenos Aires: Siglo XXI, 2006.

Rodríguez, Alejandra. Historia, pueblos originarios y frontera en el cine nacional, Bernal: Universidad Nacional de Quilmes, 2015.

Silva Escobar, Juan Pablo y Valentina Raurich Valencia. "Emergente, Dominante y Residual. Una mirada sobre la fabricación de lo popular realizada por el Nuevo Cine Chileno (1958 -1973)". Aisthesis 47, Instituto de Estética Pontificia Universidad Católica de Chile, (2010): 64-82. http://www.scielo.cl/scielo.php?script=sci_arttext\&pid=S071871812010000 100005\&lng=es\&tlng=es. 10.4067/S0718-71812010000100005. $03 \mathrm{de}$ septiembre de 2017.

Sorlin, Pierre. Sociología del cine. La apertura para la historia del mañana. México: Fondo de Cultura Económica, 1985.

Tal, Tzvi. Pantallas y Revolución. Una visión comparativa del Cine Liberación y el Cinema Novo, Buenos Aires: Lumiere, 2005.

Torre, Claudia. Literatura en tránsito. La narrativa expedicionaria de la Conquista del Desierto, Buenos Aires: Prometo, 2010.

Tranchini, Elina, "El imaginario literario sobre el mítico Sur en el road movie patagónico".Romance Quarterly, Volumen 5, Number 4, Philadelphia, (2010): 257-272.

Tschilschke, Christian von y Dagmar Schmelzer, editores. Docuficción. Enlaces entre ficción y no-ficción en la cultura española actual, Madrid-Frankfurt: Iberoamericana /Vervuert, 2010.

Uranga, Ángel. El eco de la tierra. Ensayos patagónicos, 1997-2011. Trelew:Jornada, 2011.

Vejsbjerg, Leila. "Destinos turísticos en espacios naturales de la Patagonia: las Áreas Naturales Protegidas" y "Paleoturismo en Patagonia". Patagonia Total. Antártida e Islas Malvinas, Autores varios, Colombia: BarcelBaires, 2007. 933-947 y 1062-1076. 
CATEDRAL TOMADA: Revista de crítica literaria latinoamericana / Journal of Latin American Literary Criticism El sur del Sur: cronotopías identitarias de la Patagonia en el cine argentino contemporáneo.

Williams, Raymond. (El campo y la ciudad, Buenos Aires: Paidós, 2001 . Marxismo y literatura. Barcelona: Península, 1980.

\section{Filmografía.}

La película del rey. Dir Carlos Sorín. Vicente Vigo SRL, 1986. VHS

Gerónima. Dir. Raúl Tosso. Cooperativa de Producción del Instituto de Arte Cinematográfico, 1986. VHS

Guerreros y cautivas. Dir. Edgardo Cozarinsky, Transmundo, 1989 (1994). VHS. La nave de los locos. Dir. Ricardo Willicher, Aleph SA / Cartel SA, 1994. DVD Caballos salvajes. Dir. Marcelo Piñeyro, ARTEAR SA, 1995. DVD.

Flores amarillas en la ventana. Dir. Víctor J. Ruiz, Líder Films, 1996. DVD El viento se llevó lo qué. Dir. Alejandro Agresti, Primer Plano Film Group S.A., 1998. DVD

Mundo Grúa. Dir. Pablo Trapero, Distribution Comp, 1999. DVD

Invierno mala vida. Dir. Gregorio Cramer, Primer Plano Film Group, 1999. DVD

Historias mínimas. Dir. Carlos Sorín, Distribution Company, 2002. DVD 